\title{
KLASIFIKASI KEBUTUHAN JUMLAH PRODUK MAKANAN CUSTOMER MENGGUNAKAN K-MEANS CLUSTERING DENGAN OPTIMASI PUSAT AWAL CLUSTER ALGORITMA GENETIKA
}

\author{
Yudi Istianto*'1, Shofwatul 'Uyun ${ }^{2}$ \\ ${ }^{1,2}$ Universitas Islam Negeri Sunan Kalijaga Yogyakarta \\ Email: ${ }^{1}$ yudiistiantoo@gmail.com, ${ }^{2}$ shofwatul.uyun@uin-suka.ac.id \\ *Penulis Korespondensi
}

(Naskah masuk: 01 Januari 2020, diterima untuk diterbitkan: 15 Oktober 2021)

\begin{abstract}
Abstrak
PT. Harum Bakery adalah salah satu perusahaan di Yogyakarta yang bergerak pada bidang produksi dan distribusi produk makanan roti. Setiap konsumen memiliki jumlah kebutuhan roti yang tidak teratur, sedangkan roti hanya dapat bertahan dalam waktu dua hari. Roti yang sudah berusia lebih dari dua hari akan diganti dengan yang baru oleh distributor, sehingga dapat menimbulkan kerugian bagi perusahaan. Penelitian ini mencoba untuk melakukan data mining dengan tujuan mengklasifikasikan jumlah produk makanan kepada customer menggunakan $k$-means clustering dengan optimasi pusat awal cluster algoritma genetika. Pada penelitian ini digunakan 210 data dari penjualan produk selama tiga minggu. Data tersebut akan diproses dengan menerapkan metode data mining melalui tahap preprocessing kemudian tahap klasifikasi. Preprocessing yang dilakukan antara lain, data transformation dan $k$-means clustering. Hasil dari clustering yang membutuhkan aturan tertentu lebih efektif dengan optimasi karena dari 210 data terdapat 200 data yang layak masuk tahap klasifikasi. Hasil dari pengujian mendapatkan akurasi terbaik sebesar $58.50 \%$ dan crossvalidation untuk lima fold berhasil mendapatkan rata-rata akurasi sebesar $50.58 \%$ lebih besar $2.51 \%$ dari KNN tanpa preprocessing.
\end{abstract}

Kata kunci: K-means, Clustering, Algoritma Genetika

\section{CLASSIFICATION OF NEEDS FOR THE NUMBER OF CUSTOMER FOOD PRODUCTS USING K-MEANS CLUSTERING WITH OPTIMIZATION INITIAL CLUSTER CENTER GENETIC ALGORITHM}

\begin{abstract}
PT. Harum Bakery is one of the companies in Yogyakarta engaged in the production and distribution of bakery food products. Every consumer has an irregular amount of bread needs while bread can only last for two days. Bread that is more than two days old will be replaced by a new one by the distributor which causes losses for the company. This study tries to apply data mining to classify the number of customer needs for food products using $k$-means clustering with optimization initial cluster center genetic algorithm. In this study used 210 data from product sales for three weeks. Data will be processed by applying data mining method with preprocessing before going through classification. Preprocessing includes data transformation and k-means clustering. The results of clustering that require certain rules are more effective with optimization because 210 data have 200 data that are worth entering the classification stage. The results of the test get the best accuracy of $58.50 \%$ and crossvalidation for five fold managed to get an average accuracy of $50.58 \%$ greater than $2.51 \%$ of KNN without preprocessing.
\end{abstract}

Keywords: K-means, Clustering, Genetik Algoritm

\section{PENDAHULUAN}

Perkembangan teknologi telah membawa masyarakat dalam perubahaan hidup yang lebih baik. Teknologi tidak hanya sekedar pelengkap namun telah menjadi kebutuhan hidup manusia yang tidak dapat terpisahkan. Komputer adalah salah satu teknologi yang digunakan untuk mempermudah kehidupan manusia dalam semua bidang tidak terkecuali bidang industri. Pemanfaatan ilmu komputer sangat berperan dalam penggunaan komputer yang lebih baik. Salah satu ilmu komputer yang sangat berperan ini adalah data mining. Data mining merupakan serangkaian proses untuk menggali nilai tambah berupa informasi yang selama 
ini tidak diketahui secara manual dari suatu basisdata dengan melakukan penggalian pola-pola dari data dengan tujuan untuk memanipulasi data menjadi informasi yang lebih berharga yang diperoleh dengan cara mengekstraksi dan mengenali pola yang penting atau menarik dari data yang terdapat dalam basis data.

Salah satu metode yang digunakan dalam pengolahan data adalah pengelompokkan/clustering (Rustiyan \& Mustakim, 2018). Metode algoritma Kmeans adalah metode clustering yang paling populer digunakan karena beberapa kelebihan yang dimiliki antara lain algoritma ini sederhana dan mudah diterapkan (Widiarina, 2013). Selain itu algoritma K-means tidak terpengaruh dengan adanya urutan objek (Aranda \& Natasya, 2016). Namun, K-means mempunyai kelemahan yang diakibatkan oleh penentuan pusat awal cluster. Hal ini menyebabkan hasil cluster-nya berupa solusi yang sifatnya local optimal. Menggunakan metode hierarki tertentu dapat dikolaborasikan untuk optimasi pusat awal cluster K-means. Pada penelitian yang dilakukan oleh Asroni, dkk dengan K-means clustering data penerimaan calon mahasiswa baru fakultas kedokteran dan ilmu keperawatan mampu mengelompokkan data menjadi empat kelompok dengan jumlah iterasi terbaik sebanyak tiga kali disimpulkan bahwa pendidikan dokter dan ilmu hubungan internasional menjadi jurusan pilihan calon mahasiswa baru Universitas Muhammadiyah Yogyakarta (Asroni, Fitri, \& Prasetyo, 2018). Pada penelitian yang dilakukan Aranda dan Natasya dengan K-means clustering pada sistem pendukung keputusan pemilihan konsentrasi untuk mahasiswa international class STMIK Amikom Yogyakarta berhasil diterapkan dengan jumlah iterasi terbaik sebanyak tiga kali (Aranda \& Natasya, 2016).

Salah satu algoritma yang dapat digunakan untuk optimasi adalah algoritma genetika. Algoritma Genetika merupakan metode pencarian solusi yang sesuai dengan kriteria dari banyak kombinasi solusi yang ada tanpa harus menguji satu-persatu untuk mendapatkannya. Tahap proses siklus genetika diawali dengan membangkitkan populasi awal yaitu pembangkitan sejumlah individu secara acak. Pada kasus penentuan komposisi bahan pangan untuk diet penyakit ginjal dan saluran kemih jumlah kromosom yang dibangkitkan sebanyak 20 kromosom ('Uyun \& Hartati, 2011). Pada optimasi pengantaran barang dalam perdagangan online dibangkitkan dalam satu populasi sebanyak 8 kromosom dengan panjang kromosom sebanyak 40 gen (Pratama, Djamal, \& Komarudin, 2017). Penelitian sebelumnya dalam optimasi neural network dengan algoritma genetika untuk prediksi hasil pemilukada pengujian dengan mengunakan neural network berbasis algoritma genetika didapatkan nilai accuracy $93.03 \%$ dengan nilai precision $91.28 \%$ dan nilai AUC adalah 0.971 (Badrul, 2016). Algoritma genetika telah terbukti menjadi metode yang efektif untuk digunakan dalam data mining dan pengenalan pola, Sebagian besar aplikasi algoritma genetika dalam pengenalan pola mengoptimalkan beberapa parameter dalam proses klasifikasi, algoritma genetika telah diterapkan untuk menemukan set optimal bobot fitur yang meningkatkan akurasi klasifikasi (Cantú-Paz, 2003).

Klasifikasi merupakan salah satu teknik dalam data mining. Klasifikasi adalah pemprosesan untuk menemukan sebuah model atau fungsi yang menjelaskan dan mencirikan konsep atau kelas data, untuk kepentingan tertentu (Java, Wisdayani, Nur, Wasono, \& Semarang, n.d.). Salah satu algoritma klasifikasi yang cukup popular adalah k-nearest neigbor (KNN). Dalam pengenalan pola, algoritma $k$-nearest neighbor adalah salah satu metode nonparametrik yang paling terkenal dan berguna untuk mengelompokkan objek berdasarkan fitur-fitur yang dekat. k-nearest neighbor dirancang dengan konsep bahwa label atau kelas ditentukan oleh suara mayoritas tetangganya (Won Yoon \& Friel, 2015).

PT. Harum Bakery adalah salah satu perusahaan di Yogyakarta yang bergerak pada bidang produksi dan distribusi makanan roti. PT. Harum Bakery pada saat ini mampu memproduksi kurang lebih 1000 roti dalam sehari, sebelum hari selanjutnya mereka distribusikan ke toko-toko dan pedagang jajanan pasar. Pada saat ini jumlah konsumen telah mencapai lebih dari 50 konsumen. Setiap konsumen memiliki jumlah kebutuhan roti yang tidak teratur setiap hari sedangkan roti hanya dapat bertahan dalam waktu dua hari. Roti yang sudah berusia lebih dari dua hari akan diganti dengan yang baru oleh distributor yang bisa menimbulkan kerugian bagi perusahaan. Berdasarkan latar belakang di atas maka peneliti tertarik untuk melakukan penelitian mengenai data mining untuk klasifikasi kebutuhan jumlah produk makanan customer menggunakan $k$ means clustering dengan optimasi pusat awal cluster algoritma genetika yang bermanfaat untuk mempermudah prediksi jumlah kebutuhan customer dimasa mendatang berdasarkan data penjualan masa lampau pada PT. Harum Bakery.

\section{METODE PENELITIAN}

\subsection{Jenis dan Desain Penelitian}

Metode penelitian yang digunakan adalah metode analisis deskriptif dengan pendekatan kuantitatif yang menekankan analisanya terhadap data-data numerik (angka). Masalah yang diteliti dalam penelitian ini berkaitan dengan data mining data penjualan produk. Data penjualan tersebut dianalisis dan diolah terlebih dahulu sehingga dapat dimengerti oleh komputer. Selanjutnya dilakukan proses data transformation dan clustering menggunakan metode K-means dengan optimasi penentuan pusat awal cluster dengan menggunakan algoritma genetika. Data penjualan yang telah diklaster selanjutnya diklasifikasi dengan algoritma k-nearest neighbors (KNN). Terakhir untuk mengetahui seberapa baik algoritma yang digunakan 
dilakukan pengujian dan evaluasi. Tahapan yang dilakukan pada penelitian disajikan pada Gambar 2. Proses Data Mining.

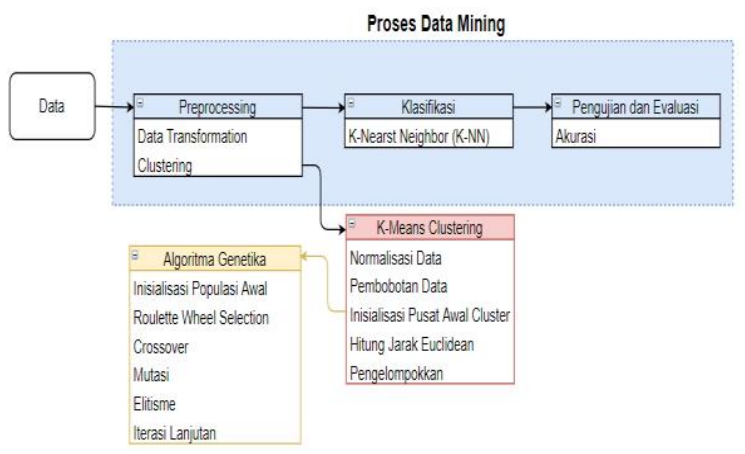

Gambar 1. Proses Data Mining

\subsection{Data}

Data merupakan penjualan produk dari distributor PT. Harum Bakery ke customer. Data tersebut merupakan penjualan produk selama tiga minggu di bulan Juli 2019. Data ini memiliki atribut antara lain disajikan pada Tabel 1. Atribut Data.

\begin{tabular}{|c|c|c|}
\hline No & Atribut & Penjelasan \\
\hline 1 & $\begin{array}{l}\text { Kode } \\
\text { Customer }\end{array}$ & $\begin{array}{l}\text { Kode dari customer yang diposisikan } \\
\text { sebagai kode yang mendeskripsikan } \\
\text { identitas customer. }\end{array}$ \\
\hline 2 & Jenis Hari & $\begin{array}{l}\text { Jenis dari hari apakah merupakan hari } \\
\text { kerja atau hari libur. }\end{array}$ \\
\hline 3 & Cuaca & Kondisi cuaca ketika transaksi. \\
\hline 4 & Hari & Nama hari ketika transaksi. \\
\hline 5 & Jual & $\begin{array}{l}\text { Jumlah penjualan produk } \\
\text { transaksi }\end{array}$ \\
\hline 6 & Retur & $\begin{array}{l}\text { Jumlah pengembalian produk ketika } \\
\text { transaksi }\end{array}$ \\
\hline 7 & Optimal & Jual dikurangi dengan retur. \\
\hline
\end{tabular}

\subsection{Preprocessing}

Pada tahap ini dilakukan untuk menyeleksi data sebelum dilakukan klasifikasi dengan tujuan meningkatkan akurasi pada tahap klasifikasi. Pada tahapan ini dilakukan antara lain data tranformation dan clustering menggunakan k-means untuk mendapatkan data latih yang baik (layak).

\subsubsection{Data Transformation}

Pada tahap ini dilakukan pengkodean dan transformasi kode atribut sesuai dengan Tabel 2 . Kode dan Transformasi Atribut.

Tabel 2. Kode dan Transformasi Atribut

\begin{tabular}{ccc}
\hline Atribut & Kode & Transform \\
& C01 & 1 \\
Kode Customer & C02 & 2 \\
C03 & 3 \\
C04 & 4 \\
C05 & 5 \\
C06 & 6 \\
C07 & 7 \\
C08 & 8 \\
C09 & 9 \\
Jenis Hari & C10 & 10 \\
Cuaca & Hari Libur & 1 \\
& Bukan Hari Libur & 2 \\
& Hujan & 1
\end{tabular}

\begin{tabular}{cc} 
Gerimis & 2 \\
Cerah & 3 \\
Berawan & 4 \\
\hline
\end{tabular}

\begin{tabular}{lcc}
\hline \multicolumn{1}{c}{ Atribut } & Kode & Transform. \\
\hline Hari & Senin & 1 \\
& Selasa & 2 \\
& Rabu & 3 \\
& Kamis & 4 \\
& Jumat & 5 \\
& Sabtu & 6 \\
& Minggu & 7 \\
\hline Jumlah Jual & Tetap & Tetap \\
\hline Jumlah Retur & Tetap & Tetap \\
\hline Jumlah Optimal & Tetap & Tetap \\
\hline
\end{tabular}

\subsubsection{K-means Clustering}

Pada penelitian ini menggunakan $k$-means untuk melakukan clustering data. Pendekatan untuk membuat cluster mendikte keanggotaan dalam grup berdasarkan tingkat persamaan. Setiap cluster haruslah memiliki rentang nilai tertentu berdasarkan aturan (rule) dari Tabel 3. Rule Cluster.

Tabel 3. Rule Cluster

\begin{tabular}{lc}
\hline \multicolumn{1}{c}{ Jumlah Optimal } & Cluster \\
\hline optimal $<=10$ & $\mathrm{C} 1$ \\
optimal $>10 \&$ optimal $<=20$ & $\mathrm{C} 2$ \\
optimal $>20$ \& optimal $<=30$ & $\mathrm{C} 3$ \\
optimal $>30$ \& optimal $<=40$ & $\mathrm{C} 4$ \\
optimal $>40 \&$ optimal $<=50$ & $\mathrm{C} 5$ \\
\hline
\end{tabular}

\subsubsection{Normalisasi Data}

Suatu data nilai atributnya haruslah bernilai setara untuk dilakukan clustering, hal ini akan sangat mempengaruhi hasil pengelompokkan data nantinya. Pada tahap normalisasi data pada penelitian ini rasio normalisasi atribut diusulkan persamaan sebagai berikut Tabel 4. Rasio Normalisasi Atribut.

\begin{tabular}{llc}
\multicolumn{3}{c}{ Tabel 4. Rasio Normalisasi Atribut } \\
\hline Atribut & \multicolumn{1}{c}{ Normalisasi } & Kode \\
\hline $\begin{array}{l}\text { Kode } \\
\text { Customer }\end{array}$ & $\begin{array}{l}\text { Jumlah optimal per customer / jumlah } \\
\text { transaksi per customer }\end{array}$ & A1 \\
Jenis & $\begin{array}{l}\text { Jumlah optimal per jenis hari / jumlah } \\
\text { transaksi per jenis hari }\end{array}$ & A2 \\
Hari & Jumlah optimal per cuaca / jumlah & A3 \\
Cuaca & transaksi per cuaca & \\
& Jumlah optimal per hari / jumlah & A4 \\
Hari & transaksi per hari & \\
& Tetap A5 & A6 \\
Jual & Tetap & A7 \\
Retur & Tetap & \\
Optimal & &
\end{tabular}

\subsubsection{Pembobotan Data}

Pembobotan data digunakan untuk mendapatkan bobot yang nantinya akan berguna ketika proses inisialisasi pusat awal cluster. Bobot ini berasal dari nilai atribut-atribut pada record suatu data. Berikut ini adalah persamaan yang (1):

$$
\text { Bobot }=\sqrt{A 1^{2}+A 2^{2}+\cdots+A n^{2}}
$$




\subsubsection{Inisialisasi Pusat Awal Cluster}

Penelitian ini mencoba melakukan optimasi pada langkah pembangkitan pusat awal cluster menggunakan algoritma genetika. Dipilih sebanyak lima data random yang berbeda selanjutnya akan dihitung fitness terbaik yang akan menjadi lima pusat cluster terbaik.

Populasi awal terdiri dari empat kromosom dengan lima gen yang mewakili anggota kelompok cluster. Berdasarkan rule sesuai Tabel 3. Rule Cluster dibuatlah poulasi awal dengan usulan Tabel 5. Pembentukan Kromosom.

\begin{tabular}{cllllll}
\multicolumn{7}{c}{ Tabel 5. Pembentukan Kromosom } \\
\hline No & Krom. & Gen & Gen & Gen & Gen & Gen \\
& & $\mathbf{1}$ & $\mathbf{2}$ & $\mathbf{3}$ & $\mathbf{4}$ & $\mathbf{5}$ \\
\hline 1 & Krom.1 & G11 & G21 & G31 & G41 & G51 \\
2 & Krom.2 & G12 & G22 & G32 & G42 & G52 \\
$\ldots$ & $\ldots$ & $\ldots$ & $\ldots$ & $\ldots$ & $\ldots$ & $\ldots$ \\
n & Krom.n & G1n & G2n & G3n & G4n & G5n \\
\hline
\end{tabular}

Evaluasi digunakan untuk menghitung fitness pada tiap kromosom. Evaluasi nilai fitness dalam penelitian ini menggunakan rumus aritmatika dengan tetap memperhatikan rule. Tujuannya adalah mencari deret angka yang hilang berdasarkan dengan angka yang telah diketahui. Berikut ini adalah persamaan yang diusulkan untuk menghitung fitness (2):

1. Inisialisasi nilai $\mathrm{N}$ :

$$
N=\frac{\left(\text { Gen }_{n}-\text { Gen }_{1}\right)}{\text { (Jumlah Gen }-1)}
$$

2. Inisialisasi nilai sejumlah Gen :

$$
\begin{aligned}
& C_{2}=\operatorname{Gen}_{2}+(N *(2-1)) \\
& \ldots \\
& C_{(n-1)}=\operatorname{Gen}_{(n-1)}+(N *(n-1))
\end{aligned}
$$

3. Menentukan fitness kromosom:

$\overline{a b s\left(\operatorname{Gen}_{2}-C_{2}\right)+\cdots+\operatorname{abs}\left(\operatorname{Gen}_{(n-1)}-C_{(n-1)}\right)+0.01}$

\subsubsection{Hitung Jarak Euclidean}

Berikut adalah persamaan dalam menghitung jarak euclidean pada tahap $k$-means clustering(3).

$$
d(P, Q)=\sqrt{\sum_{j=1}^{p}\left(x_{j}(P)-x_{j}(Q)\right)^{2}}
$$

\subsubsection{Pengelompokkan}

Pada tahap ini setelah proses hitung jarak data dikelompokkan sesuai dengan jarak terdekat dengan pusat cluter. Setelah data dikelompokkan selanjutnya adalah menilai apakah cluster yang dihasilnya sesuai dengan rule cluster Tabel 3. Data cluster yang tidak sesuai dengan rule dianggap tidak layak untuk dijadikan data latih pada tahap klasifikasi.

\subsection{K-Nearest Neighbor (K-NN) Classification}

Algoritma klasifikasi yang digunakan pada penelitian ini adalah $k$-nearest neighbors (KNN).
Prinsip kerja algoritma KNN adalah mencari jarak terdekat antara data yang dievaluasi dengan $k$ tetangga terdekatnya. Berikut adalah persamaan dalam menghitung jarak euclidean klasifikasi (4).

$$
d_{i}=\sqrt{\sum_{i=1}^{p}\left(x_{1 i}-x_{2 i}\right)^{2}}
$$

\subsection{Pengujian dan Evaluasi}

Di dalam mengukur kinerja suatu algoritma terhadap kasus tertentu umumnya dilakukan pengujian dan evaluasi. Pengujian dilakukan dengan data uji yang telah disiapkan. Pada klasifikasi data kinerja model yang dihasilkan akan menggambarkan sejauh mana model tersebut dapat mengklasifikasikan data ke dalam kelas-kelas tertentu. Pada penelitian ini untuk mengukur kinerja model yang digunakan adalah confusion matrix.

Confusion matrix adalah suatu metode yang digunakan untuk melakukan perhitungan akurasi pada konsep data mining. Akurasi merupakan suatu cara yang biasa digunakan untuk mengukur kinerja sistem klasifikasi. Perhitungan akurasi bertujuan untuk memperkirakan seberapa efektif algoritma tersebut dengan menunjukkan probabilitas nilai sebenarnya (actual) dan keseluruhan label kelas. Semakin tinggi nilai akurasi menankan semakin baik model klasifikasi yang digunakan. Akurasi didefinisikan melalui persamaan (5) (Sokolova, Japkowicz, \& Szpakowicz, 2006).

Accuracy $=\frac{T P+T N}{T P+F P+F N+T N}$

Pada pengukuran kinerja menggunakan confusion matrix terdapat empat istilah yaitu tersebut adalah True Positive (TP), True Negative (TN), False Positive (FP), dan False Negative (FN). Nilai True Negative (TN) merupakan jumlah data negatif yang terdeteksi dengan benar, sedangkan False Positive (FP) merupakan data negatif namun terdeteksi sebagai data positif. Sementara itu, True Positive (TP) merupakan data positif yang terdeteksi benar. False Negative (FN) merupakan kebalikan dari True Positive, sehingga data posifitif namun terdeteksi sebagai data negatif.

\section{LANDASAN TEORI}

\subsection{K-Means}

K-means merupakan salah satu algoritma dalam data mining yang bisa digunakan untuk melakukan clustering suatu data. Terdapat banyak pendekatan untuk membuat cluster, di antaranya adalah membuat aturan yang mendikte keanggotaan dalam grup yang sama berdasarkan tingkat persamaan di antara anggota-anggotanya. Pendekatan lainnya adalah dengan membuat sekumpulan fungsi yang mengukur beberapa properti dari pengelompokan tersebut sebagai fungsi dari beberapa parameter dari sebuah clustering. Metode $k$-means adalah metode yang termasuk dalam algoritma clustering berbasis 
jarak yang membagi data ke dalam sejumlah cluster dan algoritma ini hanya bekerja pada atribut numerik. Dasar algoritma $k$-means adalah sebagai berikut (Xu, 2010):

1. Tentukan nilai $k$ sebagai jumlah klaster yang ingin dibentuk.

2. Inisialisasi $k$ sebagai centroid yang dapat dibangkitkan secara random.

3. Hitung jarak setiap data ke masing-masing centroid menggunakan persamaan Euclidean Distance.

4. Kelompokkan setiap data berdasarkan jarak terdekat antara data dengan centroidnya.

5. Tentukan posisi centroid baru.

Kembali ke langkah 3 jika posisi centroid baru dengan centroid lama tidak sama.

\subsection{Algoritma Genetika}

Algoritma Genetika sebagai cabang dari algoritma evolusi merupakan metode yang digunakan untuk memecahkan suatu pencarian nilai dalam permasalahan-permasalahan optimasi nonlinier (Gen \& Cheng, 1999). Algoritma Genetika direpresentasikan oleh urutan langkah-langkah prosedur kromosom buatan yang bergerak dari satu populasi ke populasi baru menggunakan seleksi alami. Algoritma Genetika berbeda dengan metode konvergensi umum yang bersifat deterministik (Gen \& Cheng, 1999). Algoritma Genetika tidak berbeda dengan seleksi alam dan ilmu genetik dikarenakan algoritma ini menggunakan seleksi individu terbaik. Menurut Haupt dan Haupt (Randy \& Sue, 2004), struktur dasar algoritma genetika terdiri atas beberapa langkah yaitu sebagai berikut:

1. Inisialisasi Populasi.

2. Evaluasi Populasi.

3. Seleksi Populasi yang akan dikenai operator genetika.

4. Proses penyilangan pasangan kromosom tertentu.

5. Proses mutasi kromosom tertentu.

6. Evaluasi populasi baru (k).

7. Ulangi dari langkah 3 selama syarat berhenti belum terpenuhi.

Populasi awal pada Algoritma Genetika dibangkitkan secara acak, sedangkan populasi selanjutnya dibangkit oleh operator-operator Algoritma Genetika dari proses-proses pada generasi sebelumnya. Generasi berikutnya dibentuk dengan melalui serangkaian proses yang mirip dengan seleksi proses alamiah. Sebagian dari generasi berikutnya dibentuk dari kromosom-kromosom yang bertahan dari generasi sebelumnya, dan sebagian lainnya dilahirkan dari kromosom generasi sebelumnya.

Seperti halnya proses seleksi alam, maka dalam Algoritma Genetika juga terdapat proses yang mirip dengan proses seleksi alam yang terjadi pada setiap generasi. Jika dalam proses alamiah, hanya individu yang bugar saja yang bertahan hidup dalam populasinya, maka demikian juga dalam proses komputasi. Pada setiap generasi, kromosomkromosom akan mengalami evaluasi. Evaluasi digunakan untuk menghitung fitness pada tiap kromosom (Mu'asyaroh \& Mahmudy, 2016). Nilai fitness merupakan suatu ukuran kualitas dari tiap kromosom (Mu'asyaroh \& Mahmudy, 2016). Bentuk fungsi fitness bergantung pada masalah yang akan dioptimalisasi dan akan dibahas secara tersendiri. Nilai fitness dari suatu kromosom akan menunjukkan kualitas kromosom dalam populasi. Kromosom yang memiliki nilai fitness lebih besar akan memiliki peluang lebih besar juga dibandingkan dengan kromosom yang memiliki nilai fitness lebih kecil ('Uyun \& Hartati, 2011). Hal ini bertujuan agar populasi yang baru dibentuk dapat menghasilkan solusi yang lebih baik daripada kumpulan solusi dari populasi yang lama (Wicaksono, 2019).

Populasi generasi yang baru dibentuk dengan cara menyeleksi nilai fitness dari kromosom anak (offspring) (Badrul, 2016). Generasi berikutnya dikenal dengan istilah anak (offspring) terbentuk dari gabungan dua kromosom generasi sekarang yang bertindak sebagai induk (parent) dengan menggunakan operator penyilangan (crossover) (Badrul, 2016). Beberapa operator genetika yang paling popular antara lain: (1) selection, (2) crossover dan (3) mutation ('Uyun \& Hartati, 2011). Setelah melewati sekian iterasi, akan didapatkan individu terbaik. Individu terbaik ini akan mempunyai susunan kromosom yang bisa dikonversi menjadi solusi yang paling baik atau mendekati optimum (Mu'asyaroh \& Mahmudy, 2016). Berikut adalah cara kerja Algoritma Genetika dapat dilihat pada Gambar 2. Flowchart Algoritma Genetika.

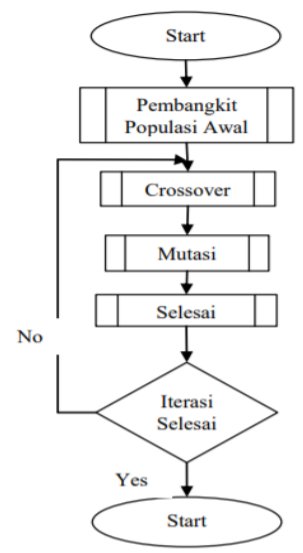

Gambar 2. Flowchart Algoritma Genetika

\section{HASIL DAN PEMBAHASAN}

\subsection{Data}

Sumber data utama yang digunakan dalam penelitian ini adalah data penjualan PT. Harum Bakery dipilih sejumlah sepuluh customer yang mempunyai konsisten melakukan transaksi selama tiga minggu. Berikut disajikan 210 data beserta 
atribut yang melekat sesuai dengan Tabel 1. Atribut Data, disajikan pada Tabel 6. Data Latih dan Uji.

Tabel 6. Kode Data Latih dan Uji

\begin{tabular}{|c|c|c|c|c|c|c|c|}
\hline No & $\begin{array}{c}\text { Cust } \\
\text { omer }\end{array}$ & $\begin{array}{l}\text { Jenis } \\
\text { Hari }\end{array}$ & $\begin{array}{c}\mathrm{Cu} \\
\mathrm{aca}\end{array}$ & $\begin{array}{c}\text { Ha } \\
\text { ri }\end{array}$ & $\begin{array}{l}\text { Ju } \\
\text { al }\end{array}$ & $\begin{array}{l}\text { Re } \\
\text { tur }\end{array}$ & $\begin{array}{l}\text { Opt } \\
\text { imal }\end{array}$ \\
\hline 1 & C10 & $\begin{array}{l}\text { Bukan } \\
\text { Hari } \\
\text { Libur }\end{array}$ & $\begin{array}{l}\mathrm{Cle} \\
\text { ar }\end{array}$ & $\begin{array}{l}\mathrm{Mi} \\
\mathrm{ng} \\
\mathrm{gu}\end{array}$ & 20 & 4 & 16 \\
\hline 2 & $\mathrm{C} 09$ & $\begin{array}{l}\text { Bukan } \\
\text { Hari } \\
\text { Libur }\end{array}$ & $\begin{array}{l}\text { Cle } \\
\text { ar }\end{array}$ & $\begin{array}{l}\mathrm{Mi} \\
\mathrm{ng} \\
\mathrm{gu}\end{array}$ & 30 & 3 & 27 \\
\hline $\begin{array}{c}\cdots \\
21 \\
0\end{array}$ & $\mathrm{C} 01$ & $\begin{array}{l}\ldots \\
\text { Bukan } \\
\text { Hari } \\
\text { Libur }\end{array}$ & $\begin{array}{l}\ldots \\
\text { Clo } \\
\text { uds }\end{array}$ & $\begin{array}{l}\cdots \\
\text { Se } \\
\text { nin }\end{array}$ & 50 & $\ldots$ & $\ldots$ \\
\hline
\end{tabular}

\subsection{Preprocessing}

Pada tahap ini dilakukan preprocessing untuk menyeleksi data sebelum dilakukan klasifikasi dengan tujuan meningkatkan akurasi pada tahap klasifikasi. Pada tahapan dilakukan antara lain data tranformation dan clustering menggunakan K-means untuk mendapatkan data latih yang baik (layak).

\subsubsection{Data Transformation}

Pada tahapan ini atribut data penjualan dikodekan sehingga menjadi data numerik sesuai dengan persamaan Tabel 2. Kode dan Transformasi Atribut. Berikut merupakan hasil dari pengodean atribut disajikan pada Tabel 7. Kode Data Latih dan Uji.

\begin{tabular}{cccccccc}
\multicolumn{8}{c}{ Tabel 7. Kode Data Latih dan Uji } \\
\hline ID & A1 & $\mathbf{A 2}$ & $\mathbf{A 3}$ & $\mathbf{A 4}$ & $\mathbf{A 5}$ & $\mathbf{A 6}$ & $\mathbf{A 7}$ \\
\hline 1 & 10 & 2 & 3 & 7 & 20 & 4 & 16 \\
2 & 9 & 2 & 3 & 7 & 30 & 3 & 27 \\
.. & $\ldots$ & $\ldots$ & $\ldots$ & $\ldots$ & $\ldots$ & $\ldots$ & $\ldots$ \\
210 & 1 & 2 & 4 & 1 & 50 & 5 & 45 \\
\hline
\end{tabular}

\subsubsection{K-Means Clustering}

Pada tahapan clustering algoritma yang digunakan adalah K-means. Tahapan K-means clustering yang digunakan pada penelitian ini antara lain adalah normalisasi data, pembobotan data, inisialisasi pusat awal cluster, hitung jarak euclidean, dan pengelompokkan.

\subsubsection{Normalisasi Data}

Dilakukan normalisasi data untuk setiap atribut sesuai dengan rasio persamaan sesuai dengan Tabel 4. Rasio Normalisasi Atribut. Pada atribut yang nilai normalisasinya tidak "tetap" akan dihitung nilai normalisasinya. Nilai normalisasi ini akan digunakan untuk mencari bobot suatu record data. Setelah setiap rasio atribut telah dihitung maka selanjutnya setiap rasio tersebut diterapkan pada setiap record data. Berikut hasil dari normalisasi data dapat dilihat pada Tabel 8. Normalisasi Data Latih dan Uji.

Tabel 8. Normalisasi Data Latih dan Uji

\begin{tabular}{cccccccc}
\hline ID & A1 & A2 & A3 & A4 & A5 & A6 & A7 \\
\hline 1 & 15.14 & 20.79 & 22.93 & 25.85 & 20 & 4 & 16 \\
2 & 15.90 & 20.79 & 22.93 & 25.85 & 30 & 3 & 27
\end{tabular}

$\begin{array}{cccccccc}\ldots & \ldots & \ldots & \ldots & \ldots & \ldots & \ldots & \ldots \\ 210 & 25.57 & 20.79 & 23.16 & 23.61 & 50 & 5 & 45\end{array}$

\subsubsection{Pembobotan Data}

Pada tahapan ini dilakukan pembobotan untuk mengetahui bobot dari data penjualan berdasarkan usulkan persamaan (1). Hasil dari pembobotan data disajikan pada Tabel 9. Bobot Data Latih dan Uji selengkapnya terdapat pada Lampiran Bobot Data Latih dan Uji. Berikut adalah detail dari perhitungan bobot yang dilakukan :

\begin{tabular}{|c|c|c|c|c|c|c|c|c|}
\hline \multicolumn{9}{|c|}{$\begin{aligned} \operatorname{Bobot}_{(1)} & =\sqrt{\begin{array}{c}15.14^{2}+20.79^{2}+22.93^{2}+25.85 \\
+20^{2}+4^{2}+16^{2}\end{array}} \\
& =50.27\end{aligned}$} \\
\hline \multicolumn{9}{|c|}{$\begin{aligned} \operatorname{Bobot}_{(2)} & =\sqrt{15.90^{2}+20.79^{2}+22.93^{2}+25.85} \\
& =59.30\end{aligned}$} \\
\hline \multicolumn{9}{|l|}{$\cdots$} \\
\hline \multicolumn{9}{|c|}{$\begin{aligned} \operatorname{Bobot}_{(210)} & =\sqrt{\begin{array}{c}25.57^{2}+20.79^{2}+23.16^{2}+25.85 \\
+50^{2}+5^{2}+16^{2}\end{array}} \\
& =82.04\end{aligned}$} \\
\hline \multicolumn{9}{|c|}{ Tabel 9. Bobot Data Latih dan Uji } \\
\hline ID & A1 & A2 & A3 & A4 & A5 & A6 & A7 & $\begin{array}{c}\text { Bo } \\
\text { bot }\end{array}$ \\
\hline 1 & $\begin{array}{r}15 \\
14\end{array}$ & $\begin{array}{r}20 . \\
79\end{array}$ & $\begin{array}{r}22 . \\
93\end{array}$ & $\begin{array}{r}25 \\
85\end{array}$ & 20 & 4 & 16 & $\begin{array}{c}50 . \\
27\end{array}$ \\
\hline 2 & $\begin{array}{r}15 . \\
90\end{array}$ & $\begin{array}{r}20 . \\
79\end{array}$ & $\begin{array}{r}22 . \\
93\end{array}$ & $\begin{array}{r}25 \\
85\end{array}$ & 30 & 3 & 27 & $\begin{array}{c}59 . \\
30\end{array}$ \\
\hline . & $\ldots$ & $\ldots$ & $\ldots$ & $\ldots$ & $\ldots$ & .. & $\ldots$ & $\ldots$ \\
\hline 210 & $\begin{array}{r}25 . \\
57\end{array}$ & $\begin{array}{r}20 . \\
79 \\
\end{array}$ & $\begin{array}{r}23 . \\
16 \\
\end{array}$ & $\begin{array}{r}23 . \\
61\end{array}$ & 50 & 5 & 45 & $\begin{array}{r}82 . \\
04\end{array}$ \\
\hline
\end{tabular}

\subsubsection{Inisialisasi Pusat Awal Cluster}

Pada penelitian ini tahapan dari proses pembangkitan pusat awal cluster menggunakan algoritma genetika antara lain inisialisasi populasi awal roulette wheel selection, crossover, mutasi, elitisme, dan iterasi lanjutan.

\subsection{Inisialisasi Populasi Awal}

Berdasarkan aturan pembangkitan populasi awal pada Tabel 5. Pembentukan Kromosom maka terbentuk populasi awal. Pada Tabel 10 kromosom-1 gen-1 nilai " 125 " berasal dari pembangkitan nilai random dari salah satu ID kromosom yang jumlah optimal <= 10 sesuai dengan persamaan pada rule Tabel 3. Rule Cluster. Hasil dari proses pembentukan populasi awal disajikan pada Tabel 10 . Populasi Awal dan fitness populasi awal pada Tabel 11. Fitness Populasi Awal.

Tabel 10. Populasi Awal

\begin{tabular}{ccccccc}
\hline No & Krom. & Gen1 & Gen2 & Gen3 & Gen4 & Gen5 \\
\hline 1 & Krom.1 & 125 & 192 & 12 & 28 & 169 \\
2 & Krom.2 & 118 & 41 & 134 & 87 & 205 \\
3 & Krom.3 & 131 & 174 & 69 & 149 & 179 \\
4 & Krom.4 & 173 & 49 & 7 & 88 & 210 \\
\hline
\end{tabular}

Kromosom 1 : 


$$
\begin{aligned}
& N=\frac{(82.47-41.27)}{(5-1)}=10.29 \\
& C_{2}=41.27+(10.29 * 1)=51.57 \\
& C_{3}=41.27+(10.29 * 2)=61.87 \\
& C_{4}=41.27+(10.29 * 3)=72.17 \\
& =\frac{1}{a b s(48.04-51.57)+a b s(53.85-61.87)} \\
& \quad+a b s(71.08-72.17)+0.01 \\
& f=\frac{1}{12.64}=0.079
\end{aligned}
$$

Kromosom 4 :

$$
\begin{aligned}
& N=\frac{(82.040-41.895)}{(5-1)}=10.036 \\
& =\frac{1}{a b s(46.94-51.93)+a b s(60.61-61.96)} \\
& \quad+a b s(72.37-72.00)+0.01 \\
& f=\frac{1}{6.7223}=0.148
\end{aligned}
$$

Tabel 11. Fitness Populasi Awal

\begin{tabular}{llrrrrrr}
\hline No & Krom. & Ge & Ge & Ge & Ge & Ge & fitness \\
& & n1 & n2 & n3 & n4 & n5 & \\
\hline 1 & Krom.1 & 41. & 48. & 53. & 71. & 82. & 0.07 \\
& & 27 & 04 & 85 & 08 & 47 & \\
2 & Krom.2 & 44. & 42. & 56. & 71. & 79. & 0.06 \\
& & 73 & 91 & 91 & 47 & 41 & \\
3 & \multirow{2}{*}{ Krom.3 } & 40. & 47. & 60. & 70. & 78. & 0.22 \\
& & 66 & 32 & 19 & 36 & 81 & \\
4 & \multirow{2}{*}{ Krom.4 } & 41. & 46. & 60. & 72. & 82. & 0.14 \\
& & 89 & 94 & 61 & 37 & 04 & \\
\hline
\end{tabular}

\subsection{Roulette Wheel Selection}

Pada tahap ini populasi awal akan dilakukan roulette wheel selection berdasarkan persamaan fitness (3). Probabilitas kromosom pada Tabel 12. Fitness dan Probabilitas dan hasil dari proses roulette wheel selection pada Tabel 13. Roulette Wheel Selection.

\begin{tabular}{cccc}
\multicolumn{4}{c}{ Tabel 12. Fitness dan Probabilitas } \\
\hline No & Krom. & fitness & Probabilitas \\
\hline 1 & Krom.1 & 0.079 & 0.153 \\
2 & Krom. 2 & 0.061 & 0.118 \\
3 & Krom.3 & 0.226 & 0.438 \\
4 & Krom.4 & 0.149 & 0.289 \\
\hline
\end{tabular}

Probabilitas :

$$
\begin{aligned}
& \text { Jumlah fitness }=0.079+0.061+0.226 \\
& +0.149 \\
& =0.514
\end{aligned}
$$

Kromosom $1: 0.079 / 0.514=0.153$

Kromosom $2: 0.061 / 0.514=0.118$

Kromosom $3: 0.226 / 0.514=0.438$

Kromosom $4: 0.149 / 0.514=0.289$

Hitung q :

$\mathrm{q} 1 \quad=0+0.153 \quad=0.153$
$\mathrm{q} 2 \quad=0.153+0.118=0.271$
$\mathrm{q} 3 \quad=0.271+0.438=0.710$
$\mathrm{q} 4 \quad=0.710+0.289=1$
Bangkitkan random:
$\mathrm{r} 1=0.163$
$\mathrm{r} 2=0.253$
$\mathrm{r} 3=0.652$
$\mathrm{r} 4=0.459$
Bandingkan:
$\mathrm{r} 1>\mathrm{q} 1 \mid 0.163>0.153 \quad$ kromosom 1 dan 2 tukar

$$
\begin{array}{ll}
\mathrm{r} 2<\mathrm{q} 2 \mid 0.253<0.271 & \text { kromosom } 2 \text { tetap } \\
\mathrm{r} 3<\mathrm{q} 3 \mid 0.652<0.710 & \text { kromosom } 3 \text { tetap } \\
\mathrm{r} 4<\mathrm{q} 4 \mid 0.459<1 & \text { kromosom } 4 \text { tetap }
\end{array}
$$

Tabel 13. Roulette Wheel Selection

\begin{tabular}{ccccccc}
\hline No & Krom. & Gen & Gen & Gen & Gen & Gen \\
& & $\mathbf{1}$ & $\mathbf{2}$ & $\mathbf{3}$ & $\mathbf{4}$ & $\mathbf{5}$ \\
\hline 1 & Krom.1 & 118 & 41 & 134 & 87 & 205 \\
2 & Krom.2 & 125 & 192 & 12 & 28 & 169 \\
\hline 3 & Krom.3 & 131 & 174 & 69 & 149 & 179 \\
4 & Krom.4 & 173 & 49 & 7 & 88 & 210 \\
\hline
\end{tabular}

\subsection{Crossover}

Pada tahap crossover akan dibangkitkan nilai random untuk setiap gen dari kromosom ganjil dan akan dibandingkan dengan probabilitas crossover. Apabila nilai random lebih kecil dari probabilitas crossover maka gen akan ditukar dengan gen dari kromosom genap dibawahnya dengan urutan gen pada kromosom sama. Hasil dari proses crossover dapat dilihat pada Tabel 14. Crossover.

\begin{tabular}{ccccccc}
\multicolumn{7}{c}{ Tabel 14. Crossover } \\
\hline No & Krom. & Gen & Gen & Gen & Gen & Gen \\
& & $\mathbf{1}$ & $\mathbf{2}$ & $\mathbf{3}$ & $\mathbf{4}$ & $\mathbf{5}$ \\
\hline 1 & Krom.1 & 125 & 192 & 12 & 28 & 169 \\
2 & Krom.2 & 118 & 41 & 134 & 87 & 205 \\
3 & Krom.3 & 173 & 49 & 7 & 88 & 179 \\
4 & Krom.4 & 131 & 174 & 69 & 149 & 210 \\
\hline
\end{tabular}

Probabilitas Crossover $=0.9 \quad P C>\mathrm{r}=$ tukar

r kromosom1 gen $1=0.669$ (tukar)

r kromosom 1 gen2 $=0.334$ (tukar)

r kromosom 1 gen $3=0.485$ (tukar)

$r$ kromosom1 gen4 $=0.195$ (tukar)

r kromosom 1 gen5 $=0.145$ (tukar)

r kromosom3 gen $1=0.222$ (tukar)

r kromosom3 gen2 $=0.097$ (tukar)

r kromosom 3 gen3 $=0.379$ (tukar)

r kromosom 3 gen $4=0.509$ (tukar)

$r$ kromosom 3 gen $5=0.976$ (tetap)

\subsection{Mutasi}

Pada tahap mutasi akan dibangkitkan nilai random untuk setiap gen dari kromosom apabila nilai random lebih kecil dari probabilitas mutasi maka gen akan diganti dengan gen baru sesuai dengan aturan Tabel 5. Pembentukan Kromosom. Hasil dari proses mutasi dapat dilihat pada Tabel 15. Mutasi.

\begin{tabular}{ccccccc}
\multicolumn{7}{c}{ Tabel 15. Mutasi } \\
\hline No & Krom. & Gen1 & Gen2 & Gen3 & Gen4 & Gen5 \\
\hline 1 & Krom.1 & 132 & 192 & 139 & 28 & 169 \\
2 & Krom.2 & 118 & 41 & 134 & 87 & 205 \\
3 & Krom.3 & 173 & 49 & 7 & 88 & 205 \\
4 & Krom.4 & 131 & 174 & 69 & 28 & 210 \\
\hline
\end{tabular}

Probabilitas Mutasi $=0.1 \mid P M>\mathrm{r}=$ ganti

r kromosom1 gen $1=0.018$ (ganti)

$r$ kromosom 1 gen2 $=0.727$ (tetap)

$r$ kromosom 1 gen $3=0.016$ (ganti)

$\mathrm{r}$ kromosom 1 gen $4=0.377$ (tetap) 
r kromosom1 gen5 $=0.845$ (tetap)

r kromosom 2 gen $1=0.945$ (tetap)

r kromosom 2 gen $2=0.768$ (tetap)

$r$ kromosom 2 gen $3=0.909$ (tetap)

$\mathrm{r}$ kromosom 2 gen $4=0.104$ (tetap)

$r$ kromosom 2 gen $5=0.202$ (tetap)

r kromosom 3 gen $1=0.615$ (tetap)

r kromosom 3 gen $2=0.853$ (tetap)

r kromosom3 gen3 $=0.282$ (tetap)

$r$ kromosom 3 gen $4=0.731$ (tetap)

$r$ kromosom 3 gen $5=0.055$ (ganti)

$\mathrm{r}$ kromosom 4 gen $1=0.852$ (tetap)

r kromosom4 gen $2=0.774$ (tetap)

$\mathrm{r}$ kromosom 4 gen $3=0.478$ (tetap)

r kromosom4 gen4 $=0.084$ (ganti)

$\mathrm{r}$ kromosom 4 gen $5=0.884$ (tetap)

\subsection{Seleksi}

Pada tahap ini dilakukan seleksi dengan cara elitisme. Jika individu hasil seleksi akan diproses lanjut dengan crossover dan mutasi, sedangkan dengan elitisme maka individu dengan kromosom terbaik dijaga. Jika menggunakan elitisme, nilai fitness individu terbaik selalu terjaga dan nilainya cenderung naik, jumlah generasi yang dipakai untuk mendapat individu terbaik yang diinginkan juga lebih sedikit. Hasil dari proses elitisme dapat dilihat pada Tabel 16. Elitisme.

Tabel 16. Elitisme

\begin{tabular}{ccccccr}
\hline No & Gen1 & Gen2 & Gen3 & Gen4 & Gen5 & fitness \\
\hline 1 & 131 & 174 & 69 & 149 & 179 & 0.226 \\
2 & 131 & 174 & 69 & 28 & 210 & 0.183 \\
3 & 131 & 174 & 69 & 149 & 210 & 0.161 \\
4 & 173 & 49 & 7 & 88 & 219 & 0.149 \\
5 & 173 & 49 & 7 & 88 & 205 & 0.149 \\
6 & 173 & 49 & 7 & 88 & 179 & 0.138 \\
7 & 132 & 192 & 139 & 28 & 169 & 0.113 \\
8 & 125 & 192 & 12 & 28 & 169 & 0.079 \\
9 & 125 & 192 & 12 & 28 & 169 & 0.079 \\
10 & 118 & 41 & 134 & 87 & 205 & 0.061 \\
11 & 118 & 41 & 134 & 87 & 205 & 0.061 \\
12 & 118 & 41 & 134 & 87 & 205 & 0.061 \\
\hline
\end{tabular}

\subsection{Iterasi Lanjutan}

Pada tahap iterasi lanjutan dilakukan pengulangan tahap algoritma genetika dari proses roulette wheel selection hingga tahap seleksi elitisme sampai ditemukan solusi terbaik dengan fitness mendekati 1 atau telah mencapai generasi maksimal. Pada penelitian ini didapatkan solusi terbaik dengan fitness 0.979 dapat dilihat pada Tabel 17. Hasil Algoritma Genetika dan Tabel 18. Hasil Percobaan Algoritma Genetika.

Tabel 17. Hasil Algoritma Genetika

\begin{tabular}{ccccccc}
\hline $\mathbf{N}$ & Gen & Gen & Gen & Gen & Gen & fitnes \\
$\mathbf{0}$ & $\mathbf{1}$ & $\mathbf{2}$ & $\mathbf{3}$ & $\mathbf{4}$ & $\mathbf{5}$ & $\boldsymbol{s}$ \\
\hline 1 & 181 & 128 & 64 & 87 & 70 & 0.979 \\
2 & 131 & 146 & 9 & 88 & 70 & 0.978 \\
$\ldots$ & $\ldots$ & $\ldots$ & $\ldots$ & $\ldots$ & $\ldots$ & $\ldots$ \\
\hline
\end{tabular}

Tabel 18. Hasil Percobaan Algoritma Genetika

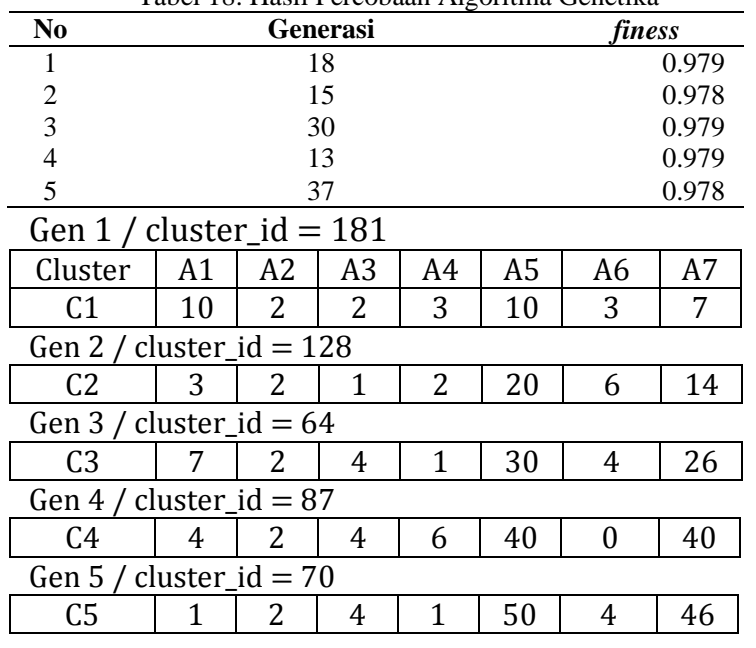

\subsubsection{Hitung Jarak Euclidean}

Berdasarkan solusi terbaik yang telah dihitung menggunakan algoritma genetika pada Tabel 17. Hasil Algoritma Genetika maka pusat cluster terbaik merupakan terjemahan gen dari kromosom terbaiknya. Hasil dari pusat awal cluster terbaik dapat diilihat Tabel 19. Pusat Awal Cluster dan Tabel 20. Normalisasi Pusat Awal Cluster.

\begin{tabular}{cccccccc}
\multicolumn{7}{c}{ Tabel 19. Pusat Awal Cluster } \\
\hline Cluster & A1 & A2 & A3 & A4 & A5 & A6 & A7 \\
\hline C1 & 10 & 2 & 2 & 3 & 10 & 3 & 7 \\
C2 & 3 & 2 & 1 & 2 & 20 & 6 & 14 \\
C3 & 7 & 2 & 4 & 1 & 30 & 4 & 26 \\
C4 & 4 & 2 & 4 & 6 & 40 & 0 & 40 \\
C5 & 1 & 2 & 4 & 1 & 50 & 4 & 46 \\
\hline
\end{tabular}

\begin{tabular}{cccccccr}
\multicolumn{7}{c}{ Tabel 20. Normalisasi Pusat Awal Cluster } \\
\hline $\begin{array}{c}\text { Clus } \\
\text { ter }\end{array}$ & $\mathbf{A 1}$ & $\mathbf{A 2}$ & $\mathbf{A 3}$ & $\mathbf{A 4}$ & $\mathbf{A 5}$ & $\mathbf{A 6}$ & $\mathbf{A 7}$ \\
\hline C1 & 15.14 & 20.79 & 18.16 & 16.56 & 10 & 3 & 7 \\
C2 & 24.19 & 20.79 & 17.42 & 19.83 & 20 & 6 & 14 \\
C3 & 23.33 & 20.79 & 23.61 & 23.16 & 30 & 4 & 26 \\
C4 & 21.33 & 20.79 & 23.61 & 21.53 & 40 & 0 & 40 \\
C5 & 25.57 & 20.79 & 23.61 & 23.16 & 50 & 4 & 46 \\
\hline
\end{tabular}

Setelah diketahui pusat cluster selanjutnya adalah menghitung jarak data uji ke pusat cluster. Hasil hitung jarak iterasi I pada disajikan pada Tabel 21. Jarak Cluster Iterasi I dan jarak iterasi II disajikan pada Tabel 24. Jarak Cluster Iterasi II.

$$
\begin{aligned}
& \boldsymbol{d}(\mathbf{1}, \mathbf{1})=\sqrt{\begin{array}{c}
(15.14-15.14)^{2}+(20.79-20.79)^{2} \\
+(25.85-18.16)^{2} \\
+(22.93-16.56)^{2}
\end{array}} \\
& =16.7799 \\
& \boldsymbol{d}(\mathbf{1 , 2})=\sqrt{\begin{array}{c}
(15.14-24.19)^{2}+(20.79-20.79)^{2} \\
+(25.85-17.42)^{2} \\
+(22.93-19.83)^{2}+(20-20)^{2} \\
+(4-6)^{2}+(16-14)^{2}
\end{array}}
\end{aligned}
$$

Tabel 21. Jarak Cluster Iterasi I 


\begin{tabular}{|c|c|c|c|c|c|c|}
\hline ID & C1 & C2 & $\mathrm{C3}$ & $\mathrm{C} 4$ & C5 & Hasil \\
\hline 1 & 16.77 & 13.05 & 16.49 & 32.20 & 43.74 & $\mathrm{C} 2$ \\
\hline 2 & 30.00 & 20.67 & 7.88 & 17.73 & 29.33 & $\mathrm{C} 3$ \\
\hline 3 & 30.95 & 18.90 & 2.70 & 16.94 & 27.83 & $\mathrm{C} 3$ \\
\hline 4 & 19.71 & 10.64 & 13.15 & 29.98 & 41.20 & $\mathrm{C} 2$ \\
\hline 5 & 17.47 & 11.93 & 14.84 & 30.96 & 42.55 & $\mathrm{C} 2$ \\
\hline 210 & 56.83 & 43.74 & 27.69 & 13.06 & 1.41 & $\mathrm{C} 5$ \\
\hline & \multicolumn{6}{|c|}{ Tabel 22. Jumlah Data Cluster Iterasi I } \\
\hline No & \multicolumn{3}{|c|}{ Cluster } & \multicolumn{2}{|c|}{ Jumlah } & \\
\hline 1 & $\mathrm{C} 1$ & & & & & 20 \\
\hline 2 & $\mathrm{C} 2$ & & & & & 82 \\
\hline 3 & $\mathrm{C} 3$ & & & & & 81 \\
\hline 4 & $\mathrm{C} 4$ & & & & & 22 \\
\hline 5 & C5 & & & & & 5 \\
\hline
\end{tabular}

Setelah diketahui anggota tiap-tiap cluster kemudian pusat cluster baru dapat dihitung berdasarkan data anggota tiap-tiap cluster baru tersebut didapat dari rumus = nilai hasil $/$ jumlah hasil. Berikut adalah detail dari perhitungan pusat cluster baru yang dilakukan.

$$
\begin{array}{ll}
\text { Cluster } 1(\mathrm{~A} 1) & =355.71 / 20=17.78 \\
\text { Cluster } 1 \text { (A2) } & =415.90 / 20=20.79 \\
\ldots . . & \\
\text { Cluster } 5 \text { (A7) } & =225 / 5=45
\end{array}
$$

\begin{tabular}{crrrrrrr} 
& \multicolumn{7}{c}{ Tabel 23. Pusat Cluster Iterasi II } \\
\hline Cluster & A1 & A2 & A3 & A4 & A5 & A6 & A7 \\
\hline C1 & 17. & 20. & 19. & 19. & 10. & 4.5 & 6.3 \\
& 78 & 79 & 61 & 18 & 18 & & \\
C2 & 19. & 20. & 20. & 20. & 20. & 5.5 & 14.71 \\
& 59 & 79 & 17 & 33 & 30 & 8 & \\
C3 & 21. & 20. & 21. & 21. & 29. & 4.7 & 25.12 \\
& 84 & 79 & 14 & 37 & 91 & 9 & \\
C4 & 23. & 20. & 22. & 21. & 40 & 4.8 & 35.18 \\
& 52 & 79 & 39 & 54 & & 1 & \\
C5 & 23. & 20. & 22. & 22. & 50 & 5 & 45 \\
& 41 & 79 & 97 & 20 & & & \\
\hline
\end{tabular}

\begin{tabular}{crrrrrr} 
& \multicolumn{6}{c}{ Tabel 24. Jarak Cluster Iterasi II } \\
\hline ID & \multicolumn{1}{c}{ C1 } & \multicolumn{1}{c}{ C2 } & \multicolumn{1}{c}{ C3 } & \multicolumn{1}{c}{ C4 } & \multicolumn{1}{c}{ C5 } & Hasil \\
\hline 1 & 15.45 & 7.94 & 15.86 & 29.20 & 42.65 & C2 \\
2 & 29.25 & 17.44 & 8.15 & 15.55 & 28.16 & C3 \\
$\ldots$ & $\ldots$ & $\ldots$ & $\ldots$ & $\ldots$ & $\ldots$ & $\ldots$ \\
210 & 55.91 & 43.06 & 28.66 & 14.30 & 2.44 & C5 \\
\hline
\end{tabular}

Pada data perhitungan jarak iterasi II dilakukan perhitungan yang sama dengan perhitungan jarak terasi I. Hasil dari kelompok cluster iterasi I dan tterasi II tidak berubah, hal ini menunjukkan bahwa pengelompokkan telah relevan.

\subsection{Pengelompokkan}

Pada tahap ini setelah proses hitung jarak data dikelompokkan sesuai dengan jarak terdekat dengan pusat cluter. Setelah data dikelompokkan selanjutnya adalah menilai apakah cluster yang dihasilnya sesuai dengan Tabel 3. Rule Cluster. Apabila data masuk kelompok dengan tidak melanggar rule maka data tersebut layak dijadikan data latih pada tahap klasifikasi. Berikut adalah hasil dari pengelompokkan dengan rule yang diberikan oleh pihak PT. Harum Bakery pada Tabel 25. Hasil Preprocessing.
Tabel 25 Hasil Preprocessing

\begin{tabular}{cllll}
\hline No & Customer & Jenis Hari & Cuaca & Hari \\
\hline 1 & C10 & Bukan Hari Libur & Clear & $\begin{array}{l}\text { Ming } \\
\text { gu }\end{array}$ \\
$\ldots$ & $\ldots$ & $\ldots$ & $\ldots$ & $\ldots$ \\
14 & C07 & Bukan Hari Libur & Rain & Sabtu \\
\hline$\ldots$ & $\ldots$ & $\ldots$ & $\ldots$ & $\ldots$ \\
210 & C01 & Bukan Hari Libur & Clouds & Senin \\
\hline \multicolumn{5}{c}{ Tabel 26 Hasil Preprocessing } \\
\hline Jual & Retur & Optimal & Cluster & Layak \\
\hline 20 & 4 & 16 & C2 & Ya \\
$\ldots$ & $\ldots$ & $\ldots$ & $\ldots$ & $\ldots$ \\
20 & 10 & 10 & C2 & Tidak \\
$\ldots$ & $\ldots$ & $\ldots$ & $\ldots$ & $\ldots$ \\
50 & 5 & 45 & C5 & Ya \\
\hline \multicolumn{7}{c}{}
\end{tabular}

\subsection{Pengujian dan Evaluasi}

Berdasarkan proses preprocessing dari 210 data ternyata hanya 200 data yang layak untuk menjadi data uji pada tahap klasifikasi. Berdasarkan 200 data sebagai data uji yang terbagi menjadi lima kelas, yaitu $\mathrm{A}(19), \quad \mathrm{B}(75), \quad \mathrm{C}(79), \quad \mathrm{D}(22)$, dan $\mathrm{E}(5)$. Pengujian yang dilakukan menggunakan confusion matrix dengan hasil pengujian disajikan pada Tabel 27. Pengujian Confusion Matrix.

Tabel 27. Pengujian Confusion Matrix

\begin{tabular}{ccccccc}
\hline & $\begin{array}{c}\text { Tru } \\
\text { e A }\end{array}$ & $\begin{array}{c}\text { True } \\
\text { B }\end{array}$ & $\begin{array}{c}\text { Tru } \\
\text { e C }\end{array}$ & $\begin{array}{c}\text { Tru } \\
\text { e D }\end{array}$ & $\begin{array}{c}\text { Tru } \\
\text { e E }\end{array}$ & $\begin{array}{c}\text { Precisio } \\
\text { n }\end{array}$ \\
\hline Pred.A & 6 & 6 & 6 & 0 & 0 & $33.33 \%$ \\
Pred.B & 13 & 52 & 11 & 2 & 0 & $66.66 \%$ \\
Pred.C & 0 & 9 & 51 & 13 & 1 & $68.91 \%$ \\
Pred.D & 0 & 6 & 8 & 6 & 2 & $27.27 \%$ \\
Pred.E & 0 & 2 & 3 & 1 & 2 & $25.00 \%$ \\
\hline Recall & 31.5 & 69.3 & 64.5 & 27.2 & 40.0 & \\
& $7 \%$ & $3 \%$ & $5 \%$ & $7 \%$ & $0 \%$ & \\
\hline
\end{tabular}

Akurasi model klasifikasi yang terbentuk dapat dihitung berdasarkan persamaan (5). Hasil dari pengujian dengan variasi $k$ pada tiap fold disajikan

\begin{tabular}{|c|c|c|c|c|c|c|c|}
\hline$k$ & $\begin{array}{c}\text { fold } \\
1\end{array}$ & $\begin{array}{c}\text { fold } \\
2\end{array}$ & $\begin{array}{c}\text { fold } \\
3\end{array}$ & $\begin{array}{c}\text { fold } \\
4\end{array}$ & $\begin{array}{c}\text { fold } \\
5\end{array}$ & Total & $\begin{array}{c}\text { Accu } \\
\text { racy }\end{array}$ \\
\hline & 25. & 42. & 35. & 37. & 40. & & \\
\hline 1 & 00 & 50 & 00 & 50 & 00 & 180 & $36 \%$ \\
\hline & 60. & 67. & 57. & 60. & 65. & & \\
\hline 2 & 00 & 50 & 50 & 00 & 00 & 310 & $62 \%$ \\
\hline & 55. & 40. & 50. & 55. & 47. & & \\
\hline 3 & 00 & 00 & 00 & 00 & 50 & 247.5 & $49.5 \%$ \\
\hline & 47. & 42. & 42. & 52. & 55. & & \\
\hline 4 & 50 & 50 & 50 & 50 & 00 & 240 & $48 \%$ \\
\hline & 55. & 45. & 50. & 62. & 52. & & \\
\hline 5 & 00 & 00 & 00 & 50 & 50 & 265 & $53 \%$ \\
\hline & 70. & 42. & 42. & 62. & 57. & & \\
\hline 6 & 00 & 50 & 50 & 50 & 50 & 275 & $55 \%$ \\
\hline & & & & & \multicolumn{2}{|c|}{ Rata-rata } & $50.58 \%$ \\
\hline
\end{tabular}
pada Tabel 28. Pengujian Crossvalidation.

Tabel 28. Pengujian Crossvalidation

Berdasarkan pengujian menggunakan confusion matrix dapat disimpulkan bahwa akurasi adalah 58.5 $\%$. Berikut ini merupakan hasil perbandingan klasifikasi KNN dan klasifikasi KNN dengan preprocessing k-means yang berbeda pada Tabel 29. Hasil Perbandingan Pengujian.

Tabel 29. Hasil Perbandingan Pengujian 


\begin{tabular}{crr}
\hline $\boldsymbol{k}$ & \multicolumn{1}{l}{ KNN } & KNN Preprocessing \\
\hline 1 & $33.33 \%$ & $34.5 \%$ \\
2 & $54.76 \%$ & $58.5 \%$ \\
3 & $46.19 \%$ & $48.00 \%$ \\
4 & $50.47 \%$ & $46.00 \%$ \\
\hline 5 & $45.23 \%$ & $45.5 \%$ \\
6 & $48.09 \%$ & $53.5 \%$ \\
\hline Rata-rata & $\mathbf{4 6 . 3 4 \%}$ & $\mathbf{4 7 . 6 7 \%}$ \\
\hline
\end{tabular}

\section{KESIMPULAN}

Berdasarkan pengujian menggunakan variasi $k$ yang berbeda pada Tabel 28. Hasil Perbandingan Pengujian, maka didapatkan hasil rata-rata akurasi klasifikasi menggunakan preprocessing mengalami peningkatan dibandingkan tanpa preprocessing. Berdasarkan hasil penelitian yang telah dilakukan maka dapat disimpulkan sebagai berikut :

1. Algoritma genetika mampu mengatasi kelemahan algoritma k-means clustering yang diakibatkan oleh penentuan pusat awal clusternya berupa solusi yang sifatnya local optimal.

2. Kinerja algoritma klasifikasi k-nearest neighbors yang menggunakan preprocessing $k$ means clustering cukup baik karena hasil pengujian berhasil mendapatkan akurasi terbaik $58.50 \%$ dan menggunakan crossvalidation berhasil mendapatkan rata-rata akurasi 50.58\% lebih besar $2.51 \%$ dari KNN tanpa preprocessing.

3. Akurasi yang didapat masih belum maksimal. Hal ini sangat dipengaruhi oleh jumlah data yang masih kurang dan memiliki jumlah kelas yang kurang merata, sehingga perlu dilakukan penambahan jumlah data dan pemerataan kelas untuk mendapatkan akurasi yang lebih baik.

\section{DAFTAR PUSTAKA}

UYUN, S., \& HARTATI, S. 2011. Penentuan Komposisi Bahan Pangan Untuk Diet Penyakit Ginjal dan Saluran Kemih dengan Algoritma Genetika. Seminar Nasional. Retrieved from http://journal.uii.ac.id/index.php/Snati/article/v iew/2196

ARANDA, J., \& NATASYA, W. A. G. 2016. Penerapan Metode K-Means Cluster Analysis Pada Sistem Pendukung Keputusan Pemilihan Konsentrasi Untuk Mahasiswa International Class Stmik Amikom Yogyakarta. Semnasteknomedia Online, 4(1), 4-2-1.

ASRONI, A., FITRI, H., \& PRASETYO, E. 2018. Penerapan Metode Clustering dengan Algoritma K-Means pada Pengelompokkan Data Calon Mahasiswa Baru di Universitas Muhammadiyah Yogyakarta (Studi Kasus: Fakultas Kedokteran dan Ilmu Kesehatan, dan Fakultas Ilmu Sosial dan Ilmu Politik). Semesta Teknika, 21(1), 60-64. https://doi.org/10.18196/st.211211

BADRUL, M. 2016. Optimasi Neural Network Dengan Algoritma Genetika Untuk Prediksi Hasil Pemilukada. Bina Insani ICT Journal, 3421, 229-242.
CANTÚ-PAZ, E. 2003. Preface. Lecture Notes in Computer Science (Including Subseries Lecture Notes in Artificial Intelligence and Lecture Notes in Bioinformatics), 2724(May 2014), VII-IX. https://doi.org/10.1007/3-54045110-2

GEN, M., \& CHENG, R. 1999. Genetic Algorithms and Engineering Optimization. Genetic Algorithms and Engineering Optimization. https://doi.org/10.1002/9780470172261

JAVA, C., WISDAYANI, D. S., NUR, I. M., WASONO, R., \& SEMARANG, U. M. (n.d.). Penerapan Algoritma K-Nearest Neighbor dalam Klasifikasi Tingkat Keparahan Korban Kecelakaan Lalu Lintas di Kabupaten Jawa Tengah. 373-380.

MU'ASYAROH, F. L., \& MAHMUDY, W. F. 2016. Implementasi Algoritma Genetika Dalam Optimasi Model AHP dan Topsis Untuk Penentuan Kelayakan Pengisian Bibit Ayam Broiler di Kandang Peternak. Jurnal Teknologi Informasi Dan Ilmu Komputer, 3(4), 226. https://doi.org/10.25126/jtiik.201634206

PRATAMA, R. A., DJAMAL, E. C., \& KOMARUDIN, A. 2017. Optimalisasi Pengantaran Barang dalam Perdagangan Online Menggunakan Algoritma Genetika. Seminar Nasional Aplikasi Teknologi Informasi (SNATi), pp. 11-15.

RANDY, L. H., \& SUE, E. H. 2004. Practical Genetic Algorithms. New York: Wiley \& Sons, Inc, 50, 62 .

RUSTIYAN, R., \& MUSTAKIM, M. 2018. Penerapan Algoritma Fuzzy C Means untuk Analisis Permasalahan Simpanan Wajib Anggota Koperasi. Jurnal Teknologi Informasi Dan Ilmu Komputer, 5(2), 171. https://doi.org/10.25126/jtiik.201852605

SOKOLOVA, M., JAPKOWICZ, N., \& SZPAKOWICZ, S. 2006. Beyond accuracy, Fscore and ROC: A family of discriminant measures for performance evaluation. Australasian Joint Conference on Artificial Intelligence, WS-06-06(c), 24-29.

WICAKSONO, S. A. 2019. Optimasi Sistem Penempatan Magang Menerapkan Algoritme Genetika. Jurnal Teknologi Informasi Dan Ilmu Komputer, 6(1), 17. https://doi.org/10.25126/jtiik.201961950

WIDIARINA. 2013. Algoritma Cluster Dinamik Untuk Optimasi Cluster Pada Algoritma KMeans Dalam Pemetaan Nasabah Potensial Algoritma Cluster Dinamik Untuk Optimasi Cluster Pada Algoritma K-Means Dalam. Tesis Magister Ilmu Komputer, Nusa Mandiri, 1(1), 33-36.

WON YOON, J., \& FRIEL, N. 2015. Efficient model selection for probabilistic $\mathrm{K}$ nearest neighbour classification. Neurocomputing, 149(PB), 
https://doi.org/10.1016/j.neucom.2014.07.023

XU, S. 2010. An expectation-maximization algorithm for the Lasso estimation of quantitative trait locus effects. Heredity, 105(5), 483-494.

https://doi.org/10.1038/hdy.2009.180 